University of South Carolina

Scholar Commons

8-1987

\title{
Research on Effective Schools: Implications for Less Developed Countries
}

Elchanan Cohn

University of South Carolina - Columbia, feu00004@moore.sc.edu

Richard A. Rossmiller

Follow this and additional works at: https://scholarcommons.sc.edu/econ_facpub

Part of the Business Commons, and the Education Commons

\section{Publication Info}

Published in Comparative Education Review, Volume 31, Issue 3, 1987, pages 377-399.

http://www.jstor.org/stable/info/1188571

(C) 1987 by University of Chicago Press

This Article is brought to you by the Economics Department at Scholar Commons. It has been accepted for inclusion in Faculty Publications by an authorized administrator of Scholar Commons. For more information, please contact digres@mailbox.sc.edu. 


\title{
Research on Effective Schools: Implications for Less Developed Countries
}

\author{
ELCHANAN COHN AND RICHARD A. ROSSMILLER
}

Publication of Equality of Educational Opportunity, ${ }^{1}$ popularly known as the Coleman Report, created the impression that schools make little, if any, difference in the learning of children and that the student's family, peers, and general social milieu exert much more of an effect on learning than does the school. A number of researchers, however, were unwilling to accept the notion that schools make no difference. Their efforts to identify and define the distinguishing characteristics of effective schools had, by the mid-1980s, generated an extensive body of literature. ${ }^{2}$ Moreover, research in developing countries, conducted mainly by World Bank staff, has generated results indicating that schools and teachers do matter, perhaps even more than socioeconomic status (SES). ${ }^{3}$ Although all the

This study was prepared for the Education and Training Department of the World Bank. The authors expressed gratitude for helpful comments on earlier drafts by the editor, anonymous referees, and by a number of World Bank staff members, especially George Psacharopoulos, Peter Moock, Jee-Peng Tan, and Stephen P. Heyneman. The authors also thank Virginia Ann Van Seters for her editorial assistance and Gloria J. Thomas for typing the final draft of the manuscript. The authors alone are responsible for any errors or points of view taken in this article.

${ }^{1}$ J. S. Coleman et al., Equality of Educational Opportunity (Washington, D.C.: U.S. Department of Health, Education, and Welfare, Office of Education, 1966).

${ }^{2}$ C. Benhow, Review of Instructionally Effective Schooling Literature (New York: Columbia University, Teachers College, ERIC Clearinghouse on Urban Education, 1980); D. Berliner, ed., Research on Teaching: Implications for Practice, proceedings from a conference sponsored by the National Institute of Education (Washington, D.C.: National Institute of Education, 1980); M. Cohen, "Effective Schools Accumulating Research Findings," American Education (January-February 1982), pp. 13-16, and "Instructional, Management and Social Conditions in Effective Schools," in School Finance and School Improvement, ed. A. Odden and L. D. Webb (Cambridge, Mass.: Ballinger, 1983), pp. 17-50; D. E. Mackenzie, "Research for School Improvement: An Appraisal of Some Recent Trends," Educational Researcher 12 (1983): 5-16; G. F. Madaus, P. W. Airasian, and T. Kellaghan, School Effectiveness: A Reassessment of the Evidence (New York: McGraw-Hill, 1981); S. C. Purkey and M. S. Smith, "Effective Schools-a Review," Elementary School Journal 83 (1983): 427-52; and M. Rutter, "School Effects on Pupil Progress: Research Findings and Policy Implications," Child Development 54 (1983): 1-29.

${ }^{3}$ S. P. Heyneman, "Influences on Academic Achievement: A Comparison of Results from Uganda and More Industrialized Societies," Sociology of Education 49 (1976): 200-11, "Differences between Developed and Developing Countries: Comment on Simmons and Alexander's 'Determinants of School Achievement," Economic Development and Cultural Change 28 (1980): 403-6, "Resource Availability, Equality, and Educational Opportunities among Nations," in Education and Development: Issues in the Analysis and Planning of Post-colonial Societies, ed. L. Anderson and D. M. Windham (Lexington, Mass.: Lexington, 1982), and "Improving the Quality of Education in Developing Countries," Finance and Development (March 1983), pp. 18-21; S. P. Heyneman and W. A. Loxley, "Influences on Academic Achievement across High- and Low-Income Countries: A Re-Analysis of IEA Data," Sociology of Education 55 (January 1982): 13-21, and "The Effect of Primary-School Quality on Academic Achievement across Twenty-Nine High- and Low-Income Countries," American Journal of Sociology 88 (1983): 1162-94; P. R. Moock and R. S. Horn, "Overview of The World Bank's Research

Comparative Education Review, vol. 31, no. 3.

(C) 1987 by the Comparative and International Education Society. All rights reserved.

$0010-4086 / 87 / 3103-0004 \$ 01.00$ 
school-effectiveness research is based on imperfect methodologies and data, the vast experience gained from research in both developed and less developed countries (LDCs) provides a few guidelines for educational policy in the developing countries.

The principal purpose of this article is to offer a review of the literature on effective schools and to draw implications for educational policy in LDCs. Because we must limit the scope of the paper if it is to be pedagogically useful, we will deal deliberately with the effectiveness of schools, as distinct from school systems or classrooms. Of course, a formula for successful schools implies successful classrooms, and a successful school system must have at least some successful schools, implying that any discussion of school effectiveness must take into account activities that go on in the classroom on the one hand and in the entire system on the other.

\section{Methodological Aspects of School-Effectiveness Research}

The Coleman Report, the grandfather of most school-effectiveness studies, employed multiple regression analysis to discern the proportion of variance in scholastic achievement "explained" by various factors, including SES, school-related characteristics, community-related variables, and teacher attributes. Community-related and SES variables were entered first, followed by school- and teacher-related variables. It was shown that school and teacher variables add very little to the explanatory power of the model $\left(R^{2}\right)$ once SES and other nonschool variables are taken into account. As Bowles and Levin point out, however, the methodology was deficient since the two sets of variables are correlated, so that the order in which variables are entered in the regression affects their contributions to $R^{2}$.

In a reanalysis of some of the Coleman data, Bowles and Levin show that some school-related variables have a significant effect on achievement, indicating that schools and teachers do make a difference. Their methodology was based on what is now commonly known as the "educational production function," where various inputs are entered simultaneously in a regression equation to "explain" the educational output (notably, scholastic achievement) and where the "importance" of a given input in

and Education," Canatian and International Education 12 (1983): 39-64; G. Psacharopoulos, "Educational Research at The World Bank," Research News 4 (1983): 3-17; G. Psacharopoulos and M. Woodhall, chap. 8; L. C. Solmon, "Ouality of Education and Economic Growth" Economicsersity Press, 1985). 4 (1985): 273-90; and N. Stromquist, "A Review of Educational Innovations to Reducation Review Financing Educatiomal Development: Proceedings of an International Seminar Held in Reduce Costs," in Canada, 19-21 May 1982 (Ottawa: International Development Research Centre, 1983), Sainte Marie, ${ }^{4}$ S. Bowles and H. M. Levin, "The Determinants of Scholastic Achievement: An Pp. 69-94. Some Present Findings," Journal of Human Resources 3 (1968): 3-24.

378 explaining output is based on the size and statistical significance of the regression coefficient. ${ }^{5}$

There are two distinct advantages to this model. First, $t$-tests of the regression coefficients indicate the statistical significance of each variable without the need to enter variables (or groups of variables) one at a time. Second, the regression coefficients provide an estimate of the quantitative effect on output of changing each of the inputs by a certain amount or percentage, other things being equal. If the results are robust and trustworthy, then such information is exceedingly useful for policy purposes. In contrast, when analysis of variance is used, at best we can determine which specific (or group of) variable(s) "explains" a significant proportion of the output variance. This tells us nothing, however, about the likely effect of changes in input variables on output.

The educational production function is not without deficiencies. Some contend that the regression coefficients may be quite unstable and that a significant coefficient does not imply causation. ${ }^{6}$ Policy implications are therefore tenuous. Moreover, since the output produced by schools tends to be multidimensional, the use of a single output, such as reading or math scores or even a weighted average of a number of cognitive outcomes, could lead to statistical bias. The use of simultaneous equations has been suggested, ${ }^{7}$ but only a few studies have used the technique. Moreover, if the educational process is characterized by joint production, then even simultaneous equations may not yield correct estimates.

Some school-effectiveness studies employed neither analysis of variance (or covariance) nor regression but based the results on case studies of a few schools. The typical methodology has been to observe two or more schools and-on the basis of observed differences among the schools in pupil SES, educational climate, organization, classroom procedures, and other relevant factors - to surmise which factors contribute to greater success in the schools showing higher scholastic achievement. ${ }^{8}$ Given a large number of experiments of this type, a pattern might emerge showing which school-related attributes appear to contribute consistently to higher scholastic achievement. We say "appear to" because, again, such studies do not prove causation. ${ }^{9}$

E. Cohn with S. D. Millman, Input-Output Analysis in Public Education (Cambridge, Mass. Ballinger, 1975), chap. 3; E. Cohn, Economics of Education, rev. ed. (Cambridge, Mass.: Ballinger 1979), pp. $163-74$.

I. Biniaminov and N. S. Glasman, "School Determinants of Student Achievement in Secondary Schools," American Educational Research Journal 20 (1983): 251-68.

${ }_{8}$ Cohn with Millman, chap. 3.

Andent Achievement: Schoole of a study of this type is W. B. Brookover et al., School Social Systems and ${ }_{9} \mathrm{~K}$. Doughent: Schools Can Make a Difference (New York: Praeger, 1979).

Educational Review 51 (1981): $301-8$; A. A. Summers, "Review of School Soman Report," Harvard 
To show that a particular school variable really causes a given change in educational output, it may be necessary to employ an experimenta method in which some inputs are changed, leaving all other things constant. Psychologists have employed this technique for many years, but the nature of the task permits only extremely limited experiments to be performed (e.g., comparing the efficacy of alternative teaching techniques), and, because the studies are localized, they are rarely generalizable. One example of an apparently successful experiment was the World Bank's textbook project in the Philippines ${ }^{10}$ showing the effect on achievement of a reduction in the ratio of books per pupil from $10: 1$ to $2: 1$. But this is a rare example, dealing only with one input, the results of which may or may not be generalizable to other countries.

In addition to the problems noted above, the research on effective schools suffers from other methodological problems as well. (1) The preponderance of the studies deal with elementary schools, thus making their ability to be generalized to secondary schools particularly suspect. (2) They fail to control adequately for confounding variables, such as student socioeconomic status. (3) They rely too much on case studies. (4) They use cross-sectional, rather than longitudinal, data. (5) They compare extreme outliers that are not representative of most schools.

Despite these methodological problems, however, Rosenholtz found at least three reasons to regard the findings of the effective-schools research as much more than spurious. "First, several studies describe 'turnaround' schools that, because of changes in organizational conditions, became more successful. Second, even when controlling for random error, analysts find that organizational characteristics account for 32 percent of betweenschool variance in student achievement. Third, effective schools research has been conducted within a relatively compressed time frame, not building serially from one study to the next; yet, all studies produce common findings with remarkable consistency."11

\section{Overview of the Research on School Effects in Developed Countries}

In research on school effects, two distinct lines are discernible. The first is characterized by quantitative studies using multivariate statistical analysis. The other line of research has employed a more qualitative

Achievement by Brookover et al.," Economics of Education Review 1 (1981): 397-400; B. Rowan, S. T Bossert, and D. C. Dwyer, "Research on Effective Schools: A Cautionary Note" Educational Researcher 12 (1983): $24-31$.

${ }^{10}$ S. P. Heyneman, D. T. Jamison, and X. Montenegro, "Textbooks in the Philippines: Evaluation of the Pedagogical Impact of a Nationwide Investment," Educational Evaluation and Policy Analysis 6 (1984): $139-50$.

S. J. Rosenholtz, "Effective Schools: Interpreting the Evidence," American Journal of Education 93 (1985): $352-88$. approach in the search for school effectiveness. Most of the research on the outcomes of schooling has focused on cognitive knowledge as measured the outcomes of schoovement tests. Thus, effective schools have been defined primarily in terms of gains in cognitive knowledge rather than by broader, primarily in the outcomes of schooling.

more inclusive measures of the outcomes of schooling.

The literature on school effectivents in effective schools. Mackenzie 作 for example, identified three dimensions of effective schooling-leadership efficacy, and efficiency-and core elements and facilitating elements within each of these three dimensions. ${ }^{12}$

Edmonds identified five characteristics of an effective school: $(a)$ a school principal who provides leadership and gives attention to the quality of instruction; $(b)$ a pervasive and broadly understood instructional focus; of instruction; $(b)$ a pervasive and broadly understood conducive to teaching and learning; $(d)$ an expectation that all students will obtain at least minimum mastery of a subject; and $(e)$ the use of measures of pupil achievement as the basis for program evaluation. ${ }^{13}$

The most comprehensive review of the literature on school effectivenes The methwarkey and Smith nonetheless found that certain characteristics recur regularly. They divided the studies of school effectiveness into four groups: outlier ther studies. Using information derived from these various studies, they describe the Using information derived from the variables. The first components of an effective school using two groups of variables. The first
group comprises organizational and structural variables, the second process variables. The first group of variables can be established by administrative and bureaucratic means, but the second group relates to the climate and culture of the school and cannot be accomplished by edict or through bureaucratic manipulations.

Purkey and Smith identified nine organizational/structural variables as being characteristic of effective schools.

1. Emphasis is placed on school site management, with considerable autonomy given the school leadership and staff

2. Strong instructional leadership is provided by the school principal, other administrators, or teachers (although they observed that the principal is uniquely positioned to fill this role, and his or her support is essential).

3. Stability and continuity are valued, and actions that decrease staff stability are avoided, thus facilitating agreement and cohesion.

\footnotetext{
${ }^{12}$ Mackenzie (n. 2 above).

Elends, "Programs of School Improvement: An Overview," Educational Leadership 40
} (1982): 4-11.

${ }^{4}$ Purkey and Smith (n. 2 above).

Comparative Education Review 
4. Curriculum articulation and organization are used to achieve agreement on goa's, to develop a purposeful program of instruction coordinated across grade levels, and to provide sufficient time for instruction.

5. There is a schoolwide staff development program (based on the expressed needs of teachers), involving the entire school staff and closely related to the school's instructional program.

6. Parents are informed about, and supportive of, school goals and student responsibilities, especially with regard to homework.

7. Schoolwide recognition of academic success is provided, thereby encouraging students to adopt similar norms and values.

8. Time is used effectively with more time devoted to academic subjects and less time lost to disruptions or nonacademic activities.

9. Support from the school district is evident (because, while change must occur at the building level, it is not likely to happen without support and encouragement from the central office).

The four process variables identified by Purkey and Smith relate to the culture and climate within the school.

1. Collaborative planning and collegial relationships are evident and help break down barriers, develop consensus, and promote a sense of unity.

2. There is a strong sense of community. (A feeling that one is a member of a recognizable and supportive community reduces alienation and increases commitment to school goals.)

3. Clear goals and high expectations, including clearly defined purposes and agreement on priorities, are evident.

4. Order and discipline are based on clear rules enforced fairly and consistently. ('This practice helps communicate a sense of the seriousness and purpose with which the school approaches its task.)

Purkey and Smith emphasized that the organizational/structural and process variables are interrelated and interdependent. The organizational structural variables provide a framework within which the process variables can be developed. In their view, neither group of variables, of itself, is sufficient to describe an effective school.

\section{Student Learning and School Resources}

A number of researchers have focused on students and classrooms in developed nations in an attempt to identify the most powerful determinant of student academic achievement. ${ }^{15}$ The results of these studies reveal that some variables often thought to be associated closely with school

${ }^{15}$ The growing body of literature in this area has been received and summarized by Cohn and Millman (n. 5 above), chap. 4; R. A. Rossmiller and T. G. Geske, "Economic Analysis of Education: Center for Individualized Schooling, 1977); R. G. Bridge. C. M. Judd, and P. R. Moock, The Determinant of Educational Outcomes (Cambridge, Mass.: Ballinger, 1979); Cohn (n. 5 above), chap. 8; E. A. quality account for little or none of the variance in student achievement quality ather variables generally not thought to be important appear to and the a significant bearing on students' academic achievement. For example, the level of spending per pupil, quality of the school building, and average the or class size are among the variables that do not appear to be school or colated to student achievement. On the other hand, variables cons as composition of the student body, academic emphasis of the school, such as management and discipline, use of school time, and the homeclassroom management and discipline, use of school time, and are more consistently related to student achievement. ${ }^{16}$ These results serve to buttress the findings gleaned from the effectiveschools research.

School Expenditure and Student Achievement

Conventional prescriptions for improving schools typically are quite costly and apparently not very effective. Differences in expenditure per pupil do not seem to account for significant differences in student achievement, at least at the spending levels typical of American schools. ${ }^{17}$ The lack of a close association between the amount of money spent per pupil and student achievement suggests that money is a necessary, but not a sufficient, requisite for student achievement. Rather, it is the specific resources purchased with the available funds and the uses made of these resources that are more likely to account for differences in student achievement.

Similarly, the quality of school facilities is not closely associated with student achievement in American schools. ${ }^{18}$ This finding does not mean that adequate facilities are unnecessary or unimportant; rather, it suggests that, once adequate facilities are provided, additional spending for facilities might not enhance student achievement.

Evidence concerning the relation between class size and student achievement is somewhat ambiguous. Some researchers have concluded that neither class nor school size are strongly associated with student achievement. ${ }^{19}$ On the other hand, Glass et al. argue that smaller classes

Hanushek, "Throwing Money at Schools," Journal of Policy Analysis and Management 1 (1981): 1941, and "The Economics of Schooling: Production and Efficiency in the Public Schools," Journal of Economic Literature 24 (September 1986): 1141-77; R. J. Murnane, "Interpreting the Evidence of School Effectiveness," Teachers College Record 83 (1981): 19-35, and "Input-Output Research in Education: Accomplishments, Limitations, and Lessons," in Productivnty Assessment in Education, ed. A. A. Summers (San Francisco: Jossey-Bass, 1982), pp. 5- 16; Cohen, "Instructional, Management and Social Conditions in Effective Schools" (n. 2 above); and R. A. Rossmiller, "Resource Allocation and Achievement," in A. Odden and L. D. Webb, eds. (n. 2 above), pp. 171-92.

${ }_{16}^{16}$ Rossmiller.

${ }^{17}$ Coleman et al. (n. 1 above); C. S. Jencks et al., Inequality: A Reassessment of the Effect of Family and Schooling in America (New York: Basic, 1972); Hanushek, "Throwing Money at Schools."

${ }_{19}$ Hanushek, "Throwing Money at Schools.

Fifteen Thousand Hours: Secondary Schools and Mass.: Harvard University Press, 1979); Hanushek, "Throwing Money at Schools."
382$$
1987
$$ 
do lead to improved student achievement. ${ }^{20}$ What is clear, however, is that there is no single optimum class size, since the optimum number will vary with the subject matter, the instructional mode employed, the individual students, and the degree of student mobility between classes. ${ }^{21}$ It is also evident that there is no optimum organizational structure, at least in terms of student achievement. There is no persuasive evidence, for example, that middle schools are superior to junior high schools, that homogeneous grouping of students is preferable to heterogeneous grouping, or that mainstreaming handicapped children is more effective than educating them in special classrooms.

School Characteristics and Student Achievement

There is evidence that a number of variables do affect student achievement. Among them are the leadership of the school, the composition of the student body, the academic emphasis within the school and classroom, classroom management and discipline, the use of time in school, the home environments of the students, and the professional development of the school's staff. Most of these variables relate more to the way in which resources are used-the processes of the school and classroom-than to the level of resources per se, thus lending support to the view that adequate resources are necessary, but not sufficient, to insure increased student achievement.

School leadership.-Among the attributes of effective schools commonly identified by recent studies are school site management and instructional leadership. Many researchers have concluded that leadership is necessary to initiate and maintain the school improvement process. ${ }^{22}$ Although leadership need not be restricted to the school principal, Glasman has noted that the essence of the term "school leadership" centers on the principal. ${ }^{23}$ Glasman and Biniaminov found, however, that in none of the input-output studies have attributes of school principals been used

${ }^{20}$ G. V. Glass et al., School Class Size: Research and Policy (Beverly Hills, Calif.: Sage, 1982).

${ }^{21}$ Murnane, "Input-Output Research in Education."

${ }^{22}$ D. J. Armor et al., Analysis of the School Preferred Reading Program in Selected Los Angeles Minority Schools, Report no. R-2007-L.AUSD, ERIC Document Reproduction Service no. ED130234 (Santa Monica, Calif.: Rand, 1976); P. Berman and M. W. Mcl aughlin, Federal Programs Supporting Fducational Change: Factors Affecting Implementation and Continuation, vol. 7 (Santa Monica, Calif.: Rand, 1977); W. B. Brookover and L. W. Lezotte, Changes in School Characteristics Coincident with Changes in Student Achievement, ERIC Document Reproduction Service no. ED181005 (East Lansing: Michigan State Reading Achievement Related to Eductional and En, 1979); New York State Department of Education, Reading Achievement Related to Educational and Environmental Conditions in 12 Newt York City Elementary F. Winfield, "Schools That Succeed beyond Expectations, 1974); Rutter et al.; R. L. Venezky and L. Report no. 1, ERIC Document Reproduction Service no. ED R777484 (Newark: Lniversity of Delaware 1979).

${ }^{23}$ N. S. Glasman, "Student Achievement and the School Principal," Educational Evaluation and Policy Analysis 6 (1984): 283-96.

384

August 1987 as input variables. ${ }^{24}$ This may be because the principal's influence on as input achievement typically is exercised indirectly, that is, by establishing studentive school climate, initiating goal-directed activities, emphasizing a pudent achievement, or coordinating instructional programs. Thus, while there is general agreement that leadership at the school level is a key component of effective schools, it is nevertheless a fact that researchers have not yet traced the linkages between attributes of school principals and the achievement of students in their schools. ${ }^{25}$

Student-body composition.-Several researchers have found a relation between student achievement and the composition of the school's student body. There is evidence that, ceteris paribus, student achievement is somewhat lower in schools that have a high percentage of minority, socially disadvantaged, or intellectually disadvantaged students. ${ }^{26}$ Summers and Wolfe, for example, found that the academic achievement of students in schools having a large percentage of high-achieving students in the student body is greater than would otherwise be expected. It must be noted, however, that caution is required when interpreting the relation between student body composition and student achievement because schools that enroll a large percentage of disadvantaged children frequently differ from other schools in a number of ways, some of which are likely to affect student achievement.

Academic emphasis. - The characteristics of effective schools described earlier include both organizational/structural (curriculum articulation and organization) and process (clear goals and high expectations) variables that are related to academic emphasis. The results of many studies support the view that student achievement is higher in schools and classrooms in which there is a clear focus on academic goals, appropriately structured learning activities, a teaching method that focuses on the learning task to be accomplished, and an expectation of high achievement by students. ${ }^{27}$

${ }^{24}$ N. S. Glasman and I. Biniaminov, "Input-Output Analyses of Schools," Review of Educational Research 51 (1981): 509-39.

${ }^{{ }^{25}}$ See also W. DeBevoise, "Synthesis of Research on the Principal as Instructional Leadership," Educational Leadership 41 (1984): 14-20; R. W. Eberts and J. A. Stone, "Principal Effectiveness: Using Non-experimental Data to Assess the Findings of Case Studies" (Eugene: University of Oregon, Center for Educational Policy and Management, 1985, mimeographed

${ }^{26}$ Brookover et al. (n. 8 above); Coleman et al. (n. 1 above); Jencks et al.; R. E. Klitgaard and G. R. Hall, "Are There Unusually Effective Schools?" Journal of Human Resources 10 (1975): 90-106; Rutter et al.; A. A. Summers and B. L. Wolfe, "Do Schools Make a Difference?" American Economic Review 67 (September 1977): 639-51; Glasman and Biniaminov; and R. J. Murnane, R. A. Maynard,

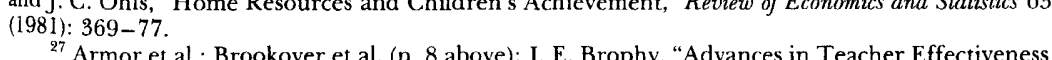

Armor et al.; Brookover et al. (n. 8 above); J. E. Brophy, "Advances in Teacher Effectiveness Research," Occasional Paper no. 18 (East Lansing: Michigan State University, Institute for Research on Teaching, 1979); T. L. Good, "Teacher Effectiveness in the Elementary School: What We Know
about It Now," Journal of Teacher Education 30 (1979): 52-64; B. C. Glenn, What Works? An Examination of Effective Schools for Poor Black Children (Cambridge, Mass.: Harvard University, Center for Law and Education, 1981); New York State Department of Education, Three Sirategies for Studying the Effects

Comparative Education Review 
Student achievement is higher when the school's staff is in general agreement on goals and objectives and expects students to achieve them. This characteristic is related to the extent to which school leadership function effectively to achieve consensus on goals and objectives (i.e., a sense of community) so that staff members are working together to achieve common objectives in a supportive environment.

There also is evidence that student achievement is enhanced when academic success is honored publicly and emphasized through the use of symbols, ceremonies, and other public recognition. ${ }^{28}$ One must caution, however, that, while effective schools emphasize high standards of academic achievement, they also adopt multiple strategies to deal with the particular needs and backgrounds of individual students. The concept of the school as a place for learning is communicated clearly to students, and a con mitment to learning is expected in every classroom.

Classroom management.-Although a commitment to learning must permeate the entire school, it is within individual classrooms, and through the efforts of individual teachers, that this commitment is given meaning. There is abundant evidence that student achievement is influenced strongly by the way teachers manage their classrooms. Effective teachers gain and hold the attention of students and maintain a classroom environment conducive to learning. They select effective modes and techniques of instruction appropriate to the learning objectives that have been established and to the learning styles of students. The atmosphere is orderly and discipline maintained. Clear and reasonable rules of conduct are enforced consistently and fairly, lessons begin and end on time, and students know what is expected of them, receive timely feedback on their performance, and are praised for good performance. ${ }^{29}$

Management of time.-Effective schools are characterized by effective use of the time available for instruction. In effective schools, a larger percentage of the school day is devoted to academic subjects, students spend more time in learning activities, and class periods are free from

of School Processes (Albany, N.Y.: Bureau of School Programs Evaluation, 1976); Rutter et al.; Venezky and Winfield; and G. Weber, Inner-City Children Can Be Taught to Read: Four Successful Schools (Washington, C.: Council for Basic Education, 1971).

Study for the 1980's, Public Hoffer, and S. Kilgore, "School and Beyond: A National Longitudinal (Chicago: National Opinion Research Center, 1981); F A W Wational Center for Education Statistics Indifferent (Lexington, Mass.: Heath, 1980); Brookover et al. (n. 8 Looking at Schools: Good, Bad, and and Rutter et al.

${ }_{29}$ J. S. Coleman, T. Hoffer, and S. Kilgore, "Cognitive Outcomes in Public and Private Schools," Sociology of Education 55 (Spring 1982): 65-76; R. R. Edmonds, "Effective Schools for the Urban Poor," Educational Leadership 37 (1979): 15-27; Armor et al.; Glenn; New York State Department of Education, Three Strategies for Studying the Effects of School Processes; Rutter et al. (n. 19 above);
Venezky and Winfield; and Weber.

August 1987 interruptions. ${ }^{30}$ Whether the analysis has been done at a macro ${ }^{31}$ or at inter school and classroom level, ${ }^{32}$ the time spent on-task in learning activities is associated positively with student achievement measures, and the relation is associated pos low-achieving students than for high-achieving students. ${ }^{33}$

Parental involvement.-Parental involvement and support are often listed as important organizational/structural variables. Several researchers have found parental involvement and support to be important factors in student achievement. ${ }^{34}$

The out-of-school activities of students have been shown to affect their school performance. Garner found a positive relation between the amount of time students spend on homework and student achievement in elementary school grades $;{ }^{35}$ and other researchers found that the academic achievement of students is related to the mother's degree of formal schooling. ${ }^{36}$ Although schools cannot control the student's home environment, activities designed to involve parents in school activities and enlist their support for these activities are likely to exert a positive influence on student achievement. Although it is possible that "involved" parents seek out more effective schools (i.e., we might have a self-selection problem), the weight of the evidence suggests that more involved parents tend to foster greater achievement motivation in their children, especially if the parents help children with homework or at least encourage children to do it. ${ }^{37}$

${ }^{30}$ Brookover et al. (n. 8 above); C. W. Fisher et al., "Teaching Behaviors, Academic Learning Time, and Student Achievement: An Overview," in Time to Learn, ed. C. Denham and A. Lieberman (Washington, D.C.: U.S. Department of Education, 1980); and J. A. Stallings, "What Research Ha to Say to Administrators of Secondary Schools about Erfective Teaching and Staff Development," in Creating Condinions for Effective Teaning, ed. K. Dock1.

${ }^{31}$ D. E. Wiley and A. Harnischfeger "Explosion of a Myth: Quantity of Schooling and Exposure Instruction, Major Educational Vehicles," Educational Research 3 (1974): 7-12; A. Harnischfeger to Instruction, Major Educational Vehicles,' Educational Research 3 (19li):" 7-12, A. Harnischfeger (1976): 18 .

${ }^{32}$ P. L. Peterson and H. J. Walberg, eds., Research and Teaching: Concepts, Findings, and Implications (Berkeley, Calif.: McCutchan, 1979); N. Karweit, "Time On-Task: A Research Review" (paper prepared for the National Commission on Educational Excellence, Washington, D.C., 1982); Rossmiller (n. 15 above); and H. J. Kielsing, "Assignment Practices and the Relationship of Instructional Time to the Reading Performance of Elementary School Children," Economics of Education Review 3 (1984): $341-50$.

${ }_{33}$ Rossmiller (n. 15 above), and "Resource Utilization in Schools and Classrooms," Program Report no. 86-7 (Madison: University of Wisconsin, Wisconsin Center for Education Research, 1986). ${ }^{34}$ Armor et al. (n. 22 above); Brookover and Lazotte (n. 22 above); D. U. Levine and J. Stark, Extended Summary and Conclusions: Institutional and Organizational Arrangements and Processes for Improving Academic Achievement at Inner City Elementary Schools (Kansas City: University of Missouri at Kansas City, Center for the Study of Metropolitan Problems in Education, 1981), Phi Delta Kappa, Why Do Indiana University 1980); and Rossmiller "Resource Utilization in Schools and Classrooms." ${ }^{35}$ T Carner "Linking School Resources to Educational Outcomes: The Role of Homework," Horace Mann-Lincoln Institute Research Bulletin 19, no. I (1978): 1-10.

${ }^{36}$ Murnane et al. (n. 2 above).

${ }^{37}$ H. W. Stevenson, S. Y. Lee, and J. W. Stigler, "Mathematics Achievement of Chinese, Japanese, and American Children," Science 231 (1986): 693-99.

Comparative Education Review 
Staff development.- Schoolwide staff-development programs that are closely related to the school's instructional program and based on the needs of teachers identified through a process of collaborative planning are characteristic of effective schools. ${ }^{38}$ This finding supports conventiong practice in that great reliance has always been placed on in-service education of teachers as a means of improving the quality of schools and school systems.

Although educational literature has emphasized the importance of continuing in-service development programs for teachers, few studies examining the intermediate and long-term effects of such programs have been conducted. The results of an intensive staff-development program for Australian educational administrators offer some encouragement with regard to the efficacy of such programs. ${ }^{39}$ Herzog's findings highlight the important role the school principal plays in encouraging and supporting the continuing professional development of teachers. ${ }^{40}$ Researchers who have studied continuing-education programs for teachers have identified several elements that appear essential, or conducive, to the success of such programs. ${ }^{41}$ Among the important elements of effective staff-development programs are (1) close collaboration between participants and program planners; (2) active involvement of the participants, for example, through role taking and the practice of new skills; (3) synthesis of content and exploration of its adaptation in diverse situations; and (4) provision of intrinsic and extrinsic rewards.

Cross-national Studies

The results of research on education in other developed countries is generally consistent with the findings of the school-effectiveness studies conducted in the United States. A study by Stevenson and others ${ }^{42}$ compared school achievement in reading and mathematics in the United States

${ }^{38}$ Armor et al. (n. 22 above); California State Department of Education, Report on the Special Studies of Selected ECE Schools with Increasing and Decreasing Reading Scores (Sacramento, Calif.: Office
of Program Evaluation and Research, 1980); Glenn (n. 27 above); Venezky and Winfield (n, 22 above

${ }^{39}$ P. F. Silver and C. R. J. Moyle, "The Impact of Intensive Inservice Programs on Educational Leaders and Their Organizations," Planning and Changing 15 (1984): 18-33.

${ }^{40}$ B. J. Herzog, "Factors That Motivate Effective Wisconsin Teachers to Engage in Continuing Professional Development" (Ph.D. diss., University of Wisconsin-Madison, 1984).

${ }^{41}$ N. A. Sprinthall and L. Thies-Sprinthall, "The Teacher as an Adult Learner," in Staff Development, ed. G. A. Griffin (Chicago: University of Chicago Press, 1983): and L. O'Neil, D. M. Estes, and J Castleberry, The State of the Art in Administrator Inservice: What Are the Best Practices? (San Antonio, Tex.: Education Service Center, Region 20, 1983).

${ }^{42}$ Stevenson et al.; Stevenson et al., "Cognitive Performance and Academic Achievement of Japanese, Chinese, and American Children," Child Development 56 (1985): 718-34; H. W. Stevenson et al., "Classroom Behavior and Achievement of Japanese, Chinese, and American Children," in
Advances in Instructional Psychology, ed. R. Glaser (Hillside, N.J.: Erlbaum, 1986); H. W. Stevenson et al. "Achievement in Mathematics," in Child Development and Education in. Japan, ed. H. Azuma, K. Habuta, and H. W. Stevenson (New York: Freeman, 1986). Minneapolis), Taiwan (Taipei), and Japan (Sendai). Carefully selected amples of 480 first- and fifth-graders chosen from 120 classrooms in 30 shools were closely tested and monion the United States tend to score lower on tests of reading comprehension in the Unid not perform a muland much statistical analysis, the researchers did find a number of attributes ivar differentiate the American from the Taiwanese and Japanese children. The following are noted.

Japanese and Taiwanese children spend more time in school and chore time studying math.

2. Japanese and Taiwanese children appear to attend (i.e., pay attention ore to the teacher.

. Japanese or the Taiwanese, with the Taiwanese appearing to spend the most time.

4. American children spend more time in play, television viewing, and 4. American children

eeping than do their counterparts in 5. American mothers greatly overestimate their children's ability and scholastic performance and generally are quite satisfied with their children's progress and the quality of programs offered by the schools. As a result, pey neither encourage their children to place greater effort on their school work nor push for school reform. In contrast, Taiwanese and school work nor push for school reform. In their children to succeed Japanese parents tend to put more pressure on their children to succeed in school and also tend to have a lower rating of their schools perform

6. Taiwanese and Japanese mothers are likelier than are their American counterparts to believe that success in life is more a function of effort than of ability.

7. Although American mothers are much more "involved" with their children than are their Taiwanese and Japanese counterparts and also tend to give their children much encouragement, they help their children less with homework and spend less time supervising their studies.

Aith homework and spend less the variables that do not appear to differ sigAlso noteworthy are those variables that nificantly between the American children on the one hand IQ SES, and wanese and Japanese children on th

teacher training and experience.

A number of other studies have appeared durional Association including the Plowden report in England, ${ }^{43}$ the for the Fvaluation of Educational Achievement (IEA) project by Unesco,

${ }^{43}$ G. F. Peaker, The Plowden Children: Four Years Later (London: National Foundation for Educationa Research in England and Wales, 1971).

ch Venture in Retrospect: The IEA Surveys," Comparative Education Review 23 (1979): $371-85$.

Compative Education Review 
and the Thorndike study. ${ }^{45}$ Although some of these studies are based on a fairly comprehensive data set, analyses of the data did not provide consistent results from which easy generalizations can follow. Nevertheless, the overall findings from these studies appear to confirm the genera conclusions discussed earlier.

\section{Research on Schools in Developing Countries}

One may question whether the results of effective schools in highly developed nations, principally the United States and Great Britain, have any application to educational policy in LDCs. Certainly, there has been little, if any, research on school effectiveness conducted in developing countries that parallels the research conducted in developed countries in recent years. Heyneman argues that the determinants of school achievement in LDCs differ from those in developed countries and advances the proposition that, as a society becomes more industrialized, school achievement is likely to be influenced more strongly by the student's socioeconomic background and other extraschool factors. ${ }^{46} \mathrm{Saha}^{47}$ contends that, "as long as the structural location of schooling in less developed societies is related to the effects of foreign penetration, the educational achievement process whereby this learning is improved will differ from that found in the developed societies." ${ }^{48} \mathrm{He}$ also postulates that, as Western education becomes less intrusive in developing societies, a student's home background will exert more of an effect on the student's school performance because the educational process will become more like that of developed societies. Given that all effective school research suffers from methodological shortcomings, ${ }^{49}$ and in light of recent research in developed countries, we conclude that, although there are differences between developed countries and LDCs (as there must be), there are also great similarities in the determinants of academic performance.

${ }^{45}$ R. L. Thorndike, "The Relation of School Achievement to Differences in the Background of Children," in Educational Policy and the International Assessment: Implications of he LEA Surveys of Education Achievement, ed. A. C. Hurves and D. V. Levine (Berkeley, Calif.: McCutchan, 1975). ${ }^{46}$ Heyneman, "Influences on Academic Achievement" (n. 3 above), and "Differences between Developed and Developing Countries" (n. 3 above).

${ }^{7}$ L. J. Saha, "Social Structure and Teacher Effects on Academic Achievement: A Comparative Analysis," Comparative Education Review 27 (1983): 69-88.

${ }^{48}$ Ibid., p. 88

(n. 26 above); R. J. Murnane and B. R. Phillips, "Learning by Doing Performance," Economics of Education of the Puzzle Relating Teaching Experience and Teaching Performance," Economics of Education Review 1 (1981): 453-65; W. W. Welch, R. E. Anderson, and L. D. Harris, "The Effects of Schooling on Mathematics Achievement," American Educational Research Education within Existing Resources: The Anderson et al.; D. Mann and D. Inman, "Improving Education Finance 10 (Fall 1984): 256-69; D. A. Rock et al., "Factors Associated with Test Score Decline: Briefing Paper" (Princeton, N.J.: Educational Testing Service, 1984), and "Determinants of Achievement Gain in High School: Briefing Paper" (Princeton, N.J.: Educational Testing Service, 1985); and R. P. Strauss and E. A. Sawyer, "Some New Evidence on 'Teacher and Student Competencies," Economics of Education Review 5 (1986): $41-48$.
A pair of distinct differences between developed countries and LDCs are considered here. First, expenditures on education in LDCs are a small fraction of those in the Western industrialized countries. For example, "in 1977 . . there were 10 pupils for each available primary school textbook in the Philippines. In Bolivia, in 1978, the monetary value invested annually in furniture and materials in the average fourth-grade classroom was approximately 80 United States cents per pupil, one-sixtieth of the investment for each pupil in Maryland (U.S.A.) during the same year. In a survey conducted in Malawi in 1979, 1 pupil in 8 was found to have a chair, and only 1 in 88 a desk." ${ }^{50}$ As a result, it might be expected that investment in textbooks and materials could have significant effects on achievement, as has been demonstrated in several studies. ${ }^{51}$

As Psacharopoulos and Woodhall point out, however, the efficacy of textbook purchases diminishes after the ratio of books per pupil approaches $1: 2$, and, furthermore, textbooks must be complemented by appropriately trained teachers and curricula. ${ }^{52}$ Moreover, in a reanalysis of IEA data, Heyneman and Loxley conclude that a larger number of school-related variables appear to influence achievement in LDCs than reported earlier, yet variables such as budget for science equipment, budget for school maintenance, and annual budget (nonteaching salary) are rarely significant for LDCs-in fact, they are more likely to be significant in developed countries such as Italy, the Netherlands, and Finland. ${ }^{53}$

The second major difference between developed countries and LDCs is the cultural factor. Worthy of note are two considerations. First; there is considerable variation in cultural factors within LDCs. More important, however, studies of LDCs generally confirm results cited earlier for developed countries concerning the effect on achievement of such factors as good classroom management, ${ }^{54}$ time on-task in reading, homework, and hours of instruction. ${ }^{55}$

But there are areas in which LDCs might benefit in ways that are not likely to be of great value in highly urbanized, developed countries. An 18.

${ }^{50}$ Heyneman, "Improving the Quality of Education in Developing Countries" (n. 3 above), p. ${ }^{51}$ S. P. Heyneman and D. T. Jamison, "Student Learning in Uganda: Textbook Availability and Other Factors," Comparative Education Review 22 (1980): 206-20; Heyneman et al. (n. 10 above); D. T. Jamison et al., "Improving Elementary Mathematics Education in Nicaragua: An Experimental Study of the Impact of Textbooks and Radio on Achievement," Journal of Educational Psychology 73 (1981): 556-67; P. Neumann and M. Cunningham, Mexico's Free Textbooks: Nationalism and the Urgency to Educate, Staff Working Paper no. 541 (Washington, D.C.: World Bank, 1982); and E. Schiefelbein, J.P. Farrell, and M. Sepulveda-Stuardo, "The Influence of School Resources in Chile," Staff Workin Paper no. 530 (Washington, D.C.: World Bank, 1983).

${ }^{53}$ Heyneman and Loxley, "Influences on Academic Achievement" (n. 3 above)

${ }^{54}$ A. M. Arriagada, "Determinants of Sixth Grade Student Achievement in Peru" (Washington, D.C.: World Bank, 1985, mimeographed).

${ }^{55}$ Heyneman and Loxley, "The Effect of Primary-School Quality on Academic Achievement across Twenty-Nine High- and Low-Income Countries" (n. 3 above).

Comparative Education Review 
example is educational radio, whose programs are directed especially to pupils in rural areas where access to schools is limited. A few studies have indicated the potential value of educational media (distance teaching). ${ }^{56}$ It has also been argued that, whereas teacher training has not been shown to affect achievement in the United States, ${ }^{57}$ different results were obtained

Simmons and Alexander, in a review of research on production functions in LDCs, conclude that essentially the same variables found to be significan (or nonsignificant) in developed countries also appear to be significant (or nonsignificant) in LDCs. ${ }^{59}$ They do point out, however, that textbooks teacher motivation, and homework appear to have a significant effect on achievement in LDCs. They conclude that "factors that have traditionally been regarded as essential for better education - higher quality teachers, more expensive facilities - do not seem to increase achievement at lower grade levels even in the poorest countries." ${ }^{, 60}$ Although subsequent studies indicate that the percentage of achievement variance "explained" by schos and teacher variables is negatively correlated with the level of a country's development, ${ }^{61}$ this does not alter the fact that studies in LDCs have, with the exceptions already noted, produced results quite similar to those derived for developed countries. ${ }^{62}$

The cumulative evidence on school effectiveness in LDCs ${ }^{63}$ suggests that school resources do indeed matter, among which one can identify in particular textbooks (up to a point), radio and other distance education, and in-service training for teachers. Class size is not consistently related to student performance, ${ }^{64}$ nor do researchers find a consistent relation between budgetary outlays and achievement. Still, school resources (as a

${ }^{56}$ Jamison et al.; D. T. Jamison and F. Orivel, "The Cost-Effectiveness of Distance Teaching for School Equivalency," in Alternative Routes to Formal Education, ed. H. Perraton (Baltimore: Johns Hopkins University Press, 1982); and K. W. Lee, "Equity and an Alternative Educational Method: A Korean Case Study," Comparative Education Review 23 (1981): 45-63.

${ }_{58}^{57}$ Psacharopoulos and Woodhall (n. 3 above), pp. 219-21.

T. Husén, L. Saha, and R. Noonan, "Teaching Training and Student Achievement in Less Developed Countries," Staff Working Paper no. 310 (Washington, D.C.: World Bank, 1978). See also Saha (n. 47 above).

Countries: A Review of L. Alexander, "The Determinants of School Achievement in Developing Countries: A Review of the Research," Economic Development and Cultural Change 26 (1978): 34 I-

${ }^{60}$ Ibid., p. 355

${ }^{61}$ Heyneman and Loxley, "The Effect of Primary-School Quality on Academic Achievement across Twenty-Nine High- and Low-Income Countries" (n. 3 above).

(n. 3 above): and for v rejoinder, seeman, "Differences between Developed and Developing Countries" (n. 3 above), and for a rejoinder, see J. Simmons, "Reply to Heyneman's Comment," Economic Devel-

${ }^{63}$ For summaries, see J. C. Eicher, "Educ.

Staff Working Paper no. 655 (Washington, D C. World Bank, 1984); Ming in Developing Countries," Psacharopoulos and Woodhall (n. 3 above), chap. 8; Simmons and Alexander; Solmon (n. 3 above): and Stromquist (n. 3 above).

${ }^{64}$ W. D. Haddad, "Educational Effects of Class Size," Staff Working Paper no. 280 (Washington, D.C.: World Bank, 1978) unit) appear to exert a significant effect on achievement, indicating that wise use of resources in LDCs should promote educational improvement.

\section{Implications for Educational Policy in LDCs ${ }^{65}$}

Prior to publication of the Coleman Report, it was widely presumed that spending more money on schools would result in scholastic improvement. The Coleman findings, followed by other studies that obtained similar results, challenge this conventional view, arguing that additional spending may have only a small effect on educational achievement. The Coleman-type findings have subsequently been challenged, and results obtained by numerous researchers in both developed and developing countries suggest that significant scholastic improvement could be achieved with a judicious allocation of funds to and within schools. Merely "throwing money at schools" may not have a significant effect on scholastic achievement; carefully selected programs, however, might have substantial effects.

Moreover, although the central government may play an important role in educational finance, educational planning, or development and administration of achievement and competency tests, most of the variables found to affect improved student performance depend on actions by personnel at the individual school level. This does not imply that rules, regulations, and requirements established by the central government or the school district are not important. It does imply that such actions must be considered carefully to insure that they do not impede or preclude potentially productive actions at the school and the classroom level of the educational enterprise.

With the foregoing limitations in mind, several implications for educational policy development may be drawn from the body of research on effective schools.

\section{School Expenditures and School Effectiveness}

While the research on effective schools provides no assurance that spending more money will result in more effective schools, neither does it establish that school expenditures are unimportant. What it does imply quite clearly is that whether spending more money will improve school effectiveness depends primarily on how the additional funds are used; that is, money is necessary but not a sufficient requisite to more effective schools. Some schools simply are more effective than are other schools even though they spend about the same average amount per student and serve comparable students. When the funding level is sufficiently high, as it generally is in the United States, schools might be able to achieve

${ }^{65}$ Suggestions addressed in this section are obviously relevant only for complete schools and school systems in which teachers, administrators, and supporting staff are regularly employed. The discussion is not relevant for incomplete schools that might comprise a limited structure, a single (frequently untrained) teacher, and no (or very few) support personnel and resources.

Comparative Education Review 
their objectives without additional funds, provided they are aware of resource reallocation strategies that could improve output. ${ }^{66}$ But technical information and expertise of this sort is often unavailable at local schools, which points to an area where higher levels of government could provide needed assistance.

The research provides no definitive answer to the question of at what level of spending do marginal returns turn down. The question is of great importance in LDCs, where expenditure per pupil is typically much lower than in the highly developed countries, from which much of the effective. schools research has emanated. It is evident that adequate facilities, equipment, books, and other instructional materials are necessary if a school is to be effective, but it is also evident that facilities and materials alone will not insure effectiveness if those who teach in them are not competent or if their decision making is unduly constrained. Conversely, highly competent teachers will find it difficult to teach effectively in inadequate facilities or if they are lacking the necessary instructional materials.

The research provides no basis for concluding that LDCs should reduce their level of expenditure for education or be unconcerned about educational facilities. The findings do suggest that, at some level (as yet undetermined but apparently reached in highly developed countries), attention must increasingly be directed to how resources are used in the educational process.

The School as a Unit of Production

The research on effective schools draws attention to the uniqueness of the individual school as a social system, and this uniqueness must be recognized and respected when formulating educational policy and planning for its implementation. While national/state policy regarding education is essential, it is at the individual school and the classroom level that teaching and learning occur. National/state policy establishes the parameters within which the individual school operates. Compulsory attendance requirements, examinations to determine admissibility to higher education, and requirements for licensure as a teacher are examples of national/state policies that establish such parameters. National/state policies cannot, however, control the teaching/learning climate in an individual school or classroom.

The research on effective schools also draws attention to the importance of the decision-making process within the school. School administrators and teachers must make a virtually endless series of day-to-day, and even minute-to-minute, decisions concerning how best to use the resources available to stimulate, encourage, and reward the learning of students.

${ }^{66}$ See E. Cohn, J. R. Sweigart, and G. R. Recves, "A New Approach to Financing Public Schools," Journal of Education Finance 6 (1980): 1-17.
It is important that national/state policies concerning education establish priate parameters for school and classroom decisions but also that appropriate parameters for school and classroom decisions that can best be made

they provide sufficient leewassoom level.

Achieving Change in Schools

The research on effective schools highlights the limitations of relying a top-down strategy to change schools and classrooms. There is ample on a top-down no matter how well planned, systematic attempts to intervene evidence that, no matter how well planned, systematic attempts in schools rarely are successful. ${ }^{67}$ Weick has described schools as " in schoo" systems with only weak linkages between administrative levels coupled" systems with only weak linkages as relatively autonomous. ${ }^{68}$ If Weick's and the classroom, which he sees as relatively autonomous in notions are correct, it is obvious that significant change in schools is unlikely to be accomplished by fiat. Rather, if one wishes to change schools, one must change the norms, behaviors, and attitudes of those who constitute one must change thization. In this view, any school-improvement strategy the school organis on achieving staff consensus on norms and goals, and this cannot be achieved through a top-down approach.

School Staffing

The task of recruiting, preparing, and retaining competent building dministrators and teachers should receive a great deal of attention, paradministrators and tesults relating teacher ticularly in LDCs. Saha summarized empirical results relache variables and student academic achievement in $21 \mathrm{LDCs}$. He found that the overall pattern of relations revealed that teacher-related variables the overall pattern of relations revealed that teacher-related exert positive effects on student achievement there may be evidence to suggest that untrained teachers can effectively there may be evidence the studies teach children literacy and numeracy, the cumulative findings in the studies strongly support the notion that trained teachers do make a difference for more advanced grades and especially for the more difficult subjects."

The research on effective schools emphasizes the importance of the indicates that available resources are used more wisely in effective schools. That that available resources are used more wisely in effective schools. That is, the decisions made about how to use the available resources affects student achievement directly, and these decisions are made by the principal and teachers. Some research in LDCs confirms the importance of the principal in enhancing achievement. ${ }^{70}$

The effective-school research also serves to underline the importance of pedagogical skills. Skill in classroom management as reflected in max-

${ }^{67}$ Berman and McLaughlin (n. 22 above)

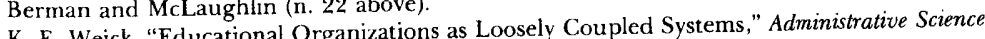
Quarterly 21 (1976): $1-19$

${ }^{69}$ Saha (n. 47 above), p. 79.

70 S. Shukla "Achievement of Indian Children in Mother Tongue (Hindi) and Science," Comparative Education Review 18 (1974): 237-47; see also Eicher.

Comparative Education Review 
imizing the time devoted to academic instruction, maintaining order and discipline, establishing clear goals and objectives, and so on was a distinguishing characteristic of effective schools. This is confirmed by som research in LDCs. ${ }^{71}$ It is quite clear that merely developing a cadre of competent personnel at the national/state level is not sufficient to insure that individual schools will be effective. It is necessary to attract competent individuals to careers in teaching, provide them with appropriate training to develop their knowledge base and pedagogical skill, and create conditions and incentives to retain able teachers and administrators in the schools. Both monetary factors (e.g., salaries and opportunities for advancement) and nonmonetary factors (e.g., status, esteem, and respect) are important. Staff Development

Despite the lack of reliable data in developed countries concerning the returns to investment in staff-development programs, such programs remain popular as a means of improving the performance of educational personnel. The research on effective schools is reassuring in that a program of staff development is characteristic of effective schools. It is important to note, however, that in the effective schools the emphasis is on schoolwide staff-development programs. Furthermore, successful programs are based on the needs of teachers as expressed by the teachers, and the teachers collaborate in planning the programs. The evidence on the efficacy of teacher training in LDCs appears stronger, as noted earlier.

While the content and substance of staff-development programs undoubtedly are important, the process used in planning and implementing such programs also is important. Clearly, those programs that are developed at the national/state level without extensive involvement of those for whom they are intended are very likely to miss the mark. When funding for staff-development programs is provided, the planning, design, and implementation of such programs should occur at the school level within parameters established by national, state, or school district policies. As emphasized earlier, these policies should provide maximum leeway to meet varying local needs and conditions. In the final analysis, the success of the best-laid plans of national/state policymakers will depend on how effectively they are implemented at the local school level.

Use of Student and Teacher Time

Evidence from both developed countries and LDCs suggests that how, and how much, time is used for both in-school and out-of-school learning may be extremely important. Although there is a debate over whether a

\footnotetext{
${ }^{7}$ Arriagada (n. 54 above); and Eicher.
}

longer school year is desirable, ${ }^{72}$ more time on-task and greater amounts of homework are practically costless yet could pay handsome dividends. Other Strategies

Since a smaller class size is not generally shown to result in greater achievement-in fact, some studies show that students perform better in a larger class $^{73}$ - it has been suggested that it might be better to increase class size and to use the extra funds for other areas such as the purchase of textbooks and other instructional or noninstructional materials. ${ }^{74}$ Since inputs are generally subject to diminishing marginal returns, the tradeoff between class size and other inputs must proceed very cautiously, preferably only if achievement is carefully monitored during the time of the experiment.

Another area of potential benefits is examination reform, as was done in Kenya. ${ }^{75}$ Since careful monitoring of student performance and the transmission of feedback information to both student and teacher appears to be a characteristic of successful schools, national efforts to develop and implement periodic testing for children might be worthwhile.

Finally, although the results for LDCs are inconclusive, ${ }^{76}$ evidence from the Perry study in Ypsilanti, Michigan, indicates that preschool programs might help youngsters from low-SES families to perform on par with their more privileged peers. ${ }^{77}$ The benefits, moreover, appear to accumulate over the years, providing a sizable return on the investment. Preschool programs might, therefore, provide benefits from both efficiency and equity standpoints.

\section{Concluding Comments and Caveats}

The arguments concerning the effect of schooling on achievement grew largely from research of Coleman et al., in which factors such as family background appear to exert far more influence than do school-

${ }^{72}$ B. Heyns, Summer Learning and the Effects of Schooling (New York: Academic Press, 1978), Dougherty (n. 9 above); and C. R. Link and J. G. Mulligan, "The Merits of a Longer School Day," Economics of Education Review 5 (1986): 373-82.

${ }^{74}$ Kielsing (n. 32 above); and Schiefelbein et al. (n. 51 above)

${ }^{74} \mathrm{Haddad}$ (n. 64 above); and Psacharopoulos and Woodhall (n. 3 above) p. 177. Experience" (Washington, D.C.: World ${ }_{76}$ M. Smilansky "Priorites

D.C.: World Bank, 1977, mimeographed); and M. Selowsky, "A Note on Preschool (Washington, Hurnan Capital in Developing Countries," Economic Development and Cultural Change 24 (July 1976) $707-19$

${ }_{77}$ J. R. Berrueta-Clement et al., Changed Lives: The Effects of the Perry Pre-School Program on Youth through Age Nineteen (Ypsilanti, Mich.: High-Scope Educational Research Foundation, 1984); and E. M. Gramlich, "Evaluation of Education Projects: The Case of the Perry Preschool Program," Economics of Education Review 5 (1986): 17-24. 
related variables on student learning. ${ }^{78}$ In addition, actions such as reducing class size, raising teacher salaries, adopting new textbooks, or improving school facilities, which involve variables much more easily manipulated than family background, appear to have little or no effect on student achievement in the United States.

The school-effectiveness studies discussed in this article, especially for developed countries, are not entirely inconsistent with the Coleman findings They do not, for example, provide evidence that easily measurable differences among schools, such as class size or teacher training and experience, are related consistently to student achievement. Rather, most of the studies of school effectiveness either have focused on individual schools or have been case studies of a few schools. The limitations of these studies must be recognized clearly when assessing their implications for educational policy.

First, most of the research on effective schools has dealt with elementary schools. The extent to which one may generalize the findings to secondary schools is indeed problematic. A related limitation is that most of the schools studied in developed countries were located in urban areas and frequently served low-income or otherwise disadvantaged students.

Second, the quality and rigor of the studies of effective schools varies widely. Some of them report only impressionistic data based on observations in two or three schools. Even those characterized by methodological rigor ${ }^{79}$ were handicapped by the need to use ex post data available from school district archives.

Third, in many instances the linkages between characteristics of effective schools and student achievement either are assumed or are exerted in directly. For example, there is general agreement that effective schools are characterized by strong leadership by the principal. As noted earlier, however, consistent and reliable evidence linking the principal's behavior directly to student achievement has not yet been found. Rather, the principal's effect on student achievement is indirect and is exerted through such means as the social climate established in the school, the employment and retention of qualified teachers, or the maintenance of appropriate order and discipline. Although the assumed relations appear to have both face validity and popular appeal, they have not been established empirically.

Fourth, in most studies achievement has been measured by the performance of students on standardized achievement tests, typically in reading and mathematics. Assuming that learning in reading and mathematics is important and that the tests used to measure such learning are valid and

${ }_{79}^{78}$ Coleman et al. (n. 1 above).

${ }^{79}$ See, e.g., R. J. Murnane, The Impact of School Resources on the Learning of Inner City Children (Cambridge, Mass.: Ballinger, 1975); and Summers and Wolfe (n. 26 above).

398 reliable, it is nevertheless true that this measure of achievement does not reliable, it the full range of the objectives of schooling.

Fifth, the research on effective schools has produced a list of ingredients

Fifth the this point, produced a recipe for an effective school. The but has not, the nocify the precise ingredients necessary for an effective research does relative importance of the various ingredients.

The strength of the effective schools research is its focus on the school

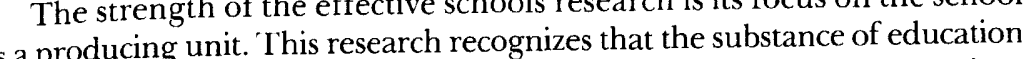
is found in classrooms and schools, not in a district central office or in a is found in class bureau. Education may, in many respects, be regarded state or national bureau. Education mast decisions concerning the application as a cottage indurces to the education of individual students are made in schools and classrooms by individual managers, that is, school principals and teachers.

Nevertheless, one may obtain some guidance for educational policy from the cumulative research in both developed countries and LDCs, as discussed in the preceding section. It must be emphasized, however, that policies to improve education in LDCs must be carefully designed and policies to im to tailor the reform to the economic and cultural background of the individual countries. There are appropriate roles for the centra government suchs as providing leadership for reform along with sources government suchs as prover indicates, however is that the principal role for educational reform lies within the individual schools in relation to the general educational climate of the school and schools in relation to the general ed resources. This is especially true for thos years and where more emphasis might be directed toward improved resource allocation rather than merely obtaining extra funds for education. In the majority of LDCs, however, where educational expenditures are woefully inadequate, extra funds for textbooks, distance education, teacher training, and other instructional and noninstructional resources could have a substantial effect on educational quality. While our survey still does not provide a precise list of priorities for the use of new funds, we have pointed out a number of possible avenues that appear to have had some success in recent years. 